\title{
Anatomy and ontogenesis of hymenopteran leaf galls of Struthanthus vulgaris Mart. (Loranthaceae)
}

\author{
JANE E. KRAUS ${ }^{1,3}$, MARCOS ARDUIN $^{2}$ and MARGARIDA VENTURELLI ${ }^{1 \dagger}$
}

(received: August 15, 2001; accepted: July 31, 2002)

\begin{abstract}
Anatomy and ontogenesis of hymenopteran leaf galls of Struthanthus vulgaris Mart. (Loranthaceae)). Leaves of Struthanthus vulgaris Mart. (Loranthaceae) exhibit galls induced by a Hymenoptera. These galls pass through five developmental stages. In the first stage, a small brown swelling is observed on the surface of the leaf. Internally, the chlorenchyma cells around the eggs of the gall-makers are divided. In the second stage, the gall enlarges and its surface assumes a wavy appearance with a depressed region in its center. Within this depression, an incompletely divided gall chamber with embryos is observed. Neoformed parenchyma is present around the chamber and the secondary walls of fibers and sclereids are no longer observed. The vascular parenchyma shows hyperplasia. In the third stage, the gall grows larger and adopts an ellipsoidal shape. Fissures appear on the gall epidermis and the neoformed parenchyma is conspicuous, with a cortical and a medullar region. In the medullar region, each gall chamber, with one inducer in larval phase, is lined with 1-2 layers of nutritive tissue. The gall is larger still at the fourth stage of development and a periderm coats most of the gall. New vascular bundles, sclereids, and fibers are formed. The gall-makers are in advanced larval phase and no nutritive tissue cells are observed. In the fifth stage, the gall reaches its definitive size and the inducers are in the pupa phase. At this stage, the cortical region undergoes slight hypertrophy. The senescent gall shows the orifices of the exit channel made by the adult gall-makers. The anatomical studies of the hymenopteran gall enabled to compare this gall with a dipteran one, previously discribed in the same plant host. It is suggested that during the maturation of the gall, specific key processes are triggered, which bring about a specific cecidogenesis.
\end{abstract}

RESUMO - (Anatomia e ontogenia de galhas foliares de Struthanthus vulgaris Mart. (Loranthaceae) causadas por himenóptero). Em folhas de Struthanthus vulgaris Mart. (Loranthaceae) foram observadas galhas induzidas por um Hymenoptera. Essas galhas apresentam cinco estágios de desenvolvimento. No primeiro estágio de desenvolvimento a galha é evidenciada como uma pequena protuberância de cor castanha na superfície da folha. Internamente ao redor dos ovos nota-se a presença de células do clorênquima divididas. No segundo estágio, a galha aumenta em tamanho e sua superfície mostra-se ondulada, com uma depressão na região central. Internamente, na região da depressão observa-se uma câmara larval incompletamente dividida, onde estão os embriões. Ao redor da câmara está presente um parênquima neoformado e as fibras e esclereídes perdem as paredes secundárias. No parênquima vascular também ocorre hiperplasia. No terceiro estágio, a galha aumenta em tamanho, assumindo um formato elipsoidal. A epiderme apresenta-se com fissuras e o parênquima neoformado é mais evidente, com uma região cortical e outra medular. Nesta, cada câmara contém um indutor em fase larval e é revestida por uma ou duas camadas de tecido nutritivo. No quarto estágio, a galha é ainda maior, sendo revestida em sua maior parte por periderme. Novos feixes vasculares, esclereídes e fibras são formados. Os indutores estão em fase larval avançada e o tecido nutritivo não é mais observado. No quinto estágio de desenvolvimento, a galha atinge o tamanho definitivo e os indutores estão em fase pupal. As células da região cortical apresentam-se ligeiramente hipertrofiadas. As galhas senescentes mostram os orifícios resultantes dos canais de emergência, feitos pelos indutores adultos. Os estudos anatômicos da galha induzida por himenóptero possibilitaram uma análise comparativa do desenvolvimento desta com outra causada por um diptero previamente descrita na mesma planta hospedeira. Sugere-se que durante a maturação da galha, processos chaves específicos são desencadeados possibilitando uma cecidogênese específica.

Key words - Hymenoptera, leaf gall, Loranthaceae, mistletoe, Struthanthus vulgaris

\section{Introduction}

Entomogenous galls represent the most intimate relationship between herbivorous insects and their host

\footnotetext{
1. Universidade de São Paulo, Departamento de Botânica, Caixa Postal 11.461, 05508-900 São Paulo, SP, Brazil.

2. Universidade Federal de São Carlos, Departamento de Botânica, Caixa Postal 676, 13565-905 São Carlos, SP, Brazil.

3. Corresponding author: kraus@usp.br
}

plants. Galls are very common in Neotropical regions, including Brazil (Fernandes et al. 1988, 1997, Monteiro et al. 1994, Lara \& Fernandes 1996, Price et al. 1998, Maia 1999, Lima et al. 2000) and they occur on plant species from several families, including the Loranthaceae (Rübsaamen 1915, Tavares 1921, Arduin et al. 1989, 1991).

Like all species of the family Loranthaceae, the members of the genus Struthanthus are hemiparasites, 
plants whose peculiar life style have been extensively studied (Kuijt 1969, Calder 1983, Bhatnaghar \& Johri 1983, Norton \& Carpenter 1998). They cause damage, often irremediable, to crops and ornamentals in many parts of the world (Hawksworth 1983, Weber 1987). Despite this damage, authors such as Marvier \& Smith (1997) defend the conservation and restoration of rare parasitic plants.

Struthanthus vulgaris Mart. (Loranthaceae) is probably the commonest mistletoe in SE Brazil and has been studied in its anatomical, physiological and phytochemical aspects (Venturelli 1984, Venturelli \& Kraus 1989, Salatino et al. 1993). Studies of galls in Loranthaceae in Brazil are confined to Rübsaamen's (1915) investigation, which described the inducer of a fruit gall, and that of Tavares (1921), who noted the presence of dipterocecidia in the roots, buds and leaves of an unidentified mistletoe. On Struthanthus vulgaris, two types of leaf galls have been observed. The first - a flattened gall - is induced by a gall-midge and was described by Arduin et al. (1991). The biometric aspects of a second type, ellipsoidal in shape, which is induced by a hymenopteran, were reported by Arduin et al. (1989). Here, in a complementary study, anatomical and ontogenetic aspects of this gall are described.

\section{Material and methods}

Specimens of Struthanthus vulgaris Mart. (Loranthaceae) with galls were located on stems of the host Tipuana tipu (Benth.) Kuntze (Leguminosae), cultivated at Universidade de São Paulo, Armando de Salles Oliveira's campus (CUASO) (São Paulo, SP, Brazil).

For anatomical analyses samples of leaves with galls, in successive stages of development, were fixed in FAA (formalin, acetic acid and 50\% ethyl alcohol, 1:1:18, v/v), dehydrated with an ethanol series, and embedded in paraffin (Johansen 1940). Transverse and longitudinal serial sections, $10 \mu \mathrm{m}$ thick, were cut with a rotary microtome. The histological sections were stained with safranin and fast green (Sass 1951) and fuchsin and astra blue (Kraus et al. 1998). Phenolic substances were detected with ferrous sulphate, as described by Johansen (1940).

\section{Results}

The leaf galls of $S$. vulgaris, induced by an insect of the order Hymenoptera, are shown in figure 1. In the first developmental stage, at least four days after oviposition, a very small swelling on the abaxial leaf epidermis is observed, and it may be seen as an irregular light brown mark. At this point, the chlorenchyma cells around the eggs of the gall-makers are divided (figure 2).

In the second developmental stage (figure 3), the gall enlarges and its surface assumes a wavy aspect with a depressed region corresponding to the light brown mark. The epidermal cells exhibit no modifications, and an incompletely divided primordial chamber with the gall-maker embryos is observed in the depressed region. The palisade and spongy parenchyma are largely unmodified near to the gall chamber, but in the swelled region, the cells of spongy parenchyma contiguous to palisade parenchyma are elongated anticlinally. These cells divide mainly in the periclinal direction, forming new cell layers. Chloroplasts may still be present in the neoformed cells. The vascular bundle shows modifications: the pericyclic fibers (figure 8) and the sclereids (figure 12) lose their lignified walls, adopting parenchymatic aspect later. Parenchyma cells also divide in the periclinal direction, separating xylem from phloem (figure 9).

In the third developmental stage (figure 4), the gall assumes an ellipsoidal shape and fissures corresponding to the rupture of the epidermis are observed. The well-developed neoformed parenchyma is characterized by a cortical and a medullar region. The medullar cells are usually slightly smaller than the cortical ones. Chloroplasts are absent in the cells of both regions. The outermost cortical cell layers present phenolic substances, which are strongly stained by safranin or basic fuchsin; the innermost cortical layers are weakly stained. Within the medullar region are the inducers, in larval phase, and there is one gall-maker per chamber. The chambers are surrounded by 1-2 layers of nutritive tissue (figure 15). At this stage, groups of neoformed parenchyma cells may resume meristematic activity (figure 10) and procambial strands are formed (figure 11). Groups of neoformed parenchyma cells can be differentiated in new sclereids, some containing crystals (figure 13 and 14).

The gall in the fourth developmental stage is larger (figure 5) and a periderm coats most of the gall. The periderm (figure 7) presents the phellem which is composed of large and slightly suberized cells loosely-packed; the phellogen consists of one layer of narrow cells, which are not always clearly observed. The gall-makers are in advanced larval phase. The inducer chambers (figure 16) are surrounded by flat cells and the nutritive tissue has disappeared. The newly-formed vascular bundles irrigate the region around the chambers (not shown). 

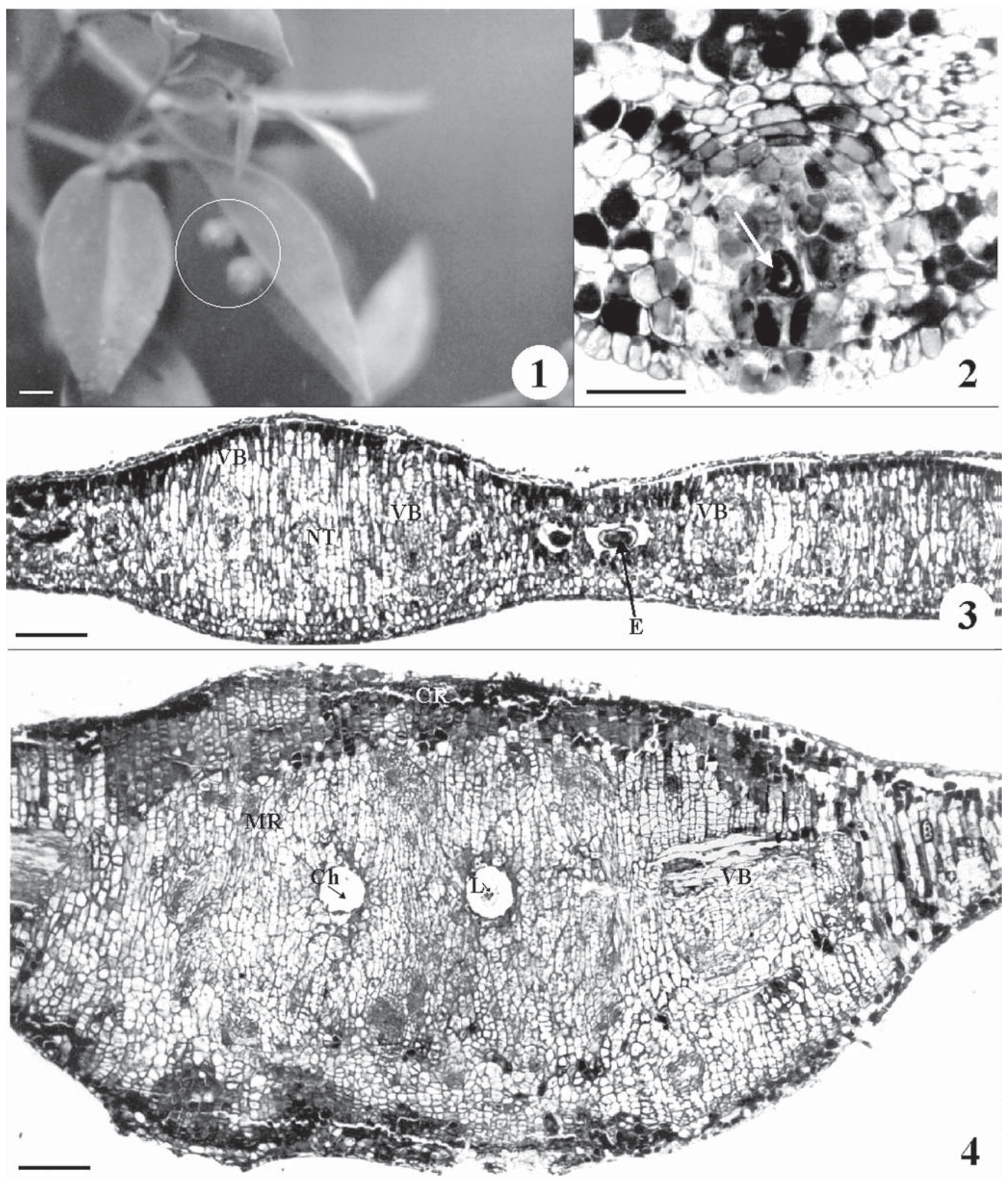

Figures 1-4. Struthanthus vulgaris leaf galls. 1. Aspect of the galls (circle). Bar $=5 \mathrm{~mm}$. 2-4. Transverse sections. 2. Stage 1 gall showing the cell proliferation around the egg (arrow). Bar $=100 \mu \mathrm{m}$. 3. Stage 2 gall showing its wavy appearance. Note the periclinal divisions of the parenchyma cells that give rise to the neoformed tissue, and the modified vascular bundles. The embryos are in an incompletely divided primordial chamber. Bar $=250 \mu \mathrm{m}$. 4. Stage 3 gall showing its ellipsoidal form. Note the cortical and medullar regions of the neoformed tissue with modified vascular bundles. The inducers are in larval phase. Bar $=200 \mu \mathrm{m} . \mathrm{Ch}=$ Chamber, $\mathrm{CR}=$ Cortical Region, $\mathrm{E}=$ Embryo, $\mathrm{L}=$ Larva, $\mathrm{MR}=$ Medullar Region, $\mathrm{NT}=$ Neoformed Tissue, $\mathrm{VB}=$ Vascular Bundle. 


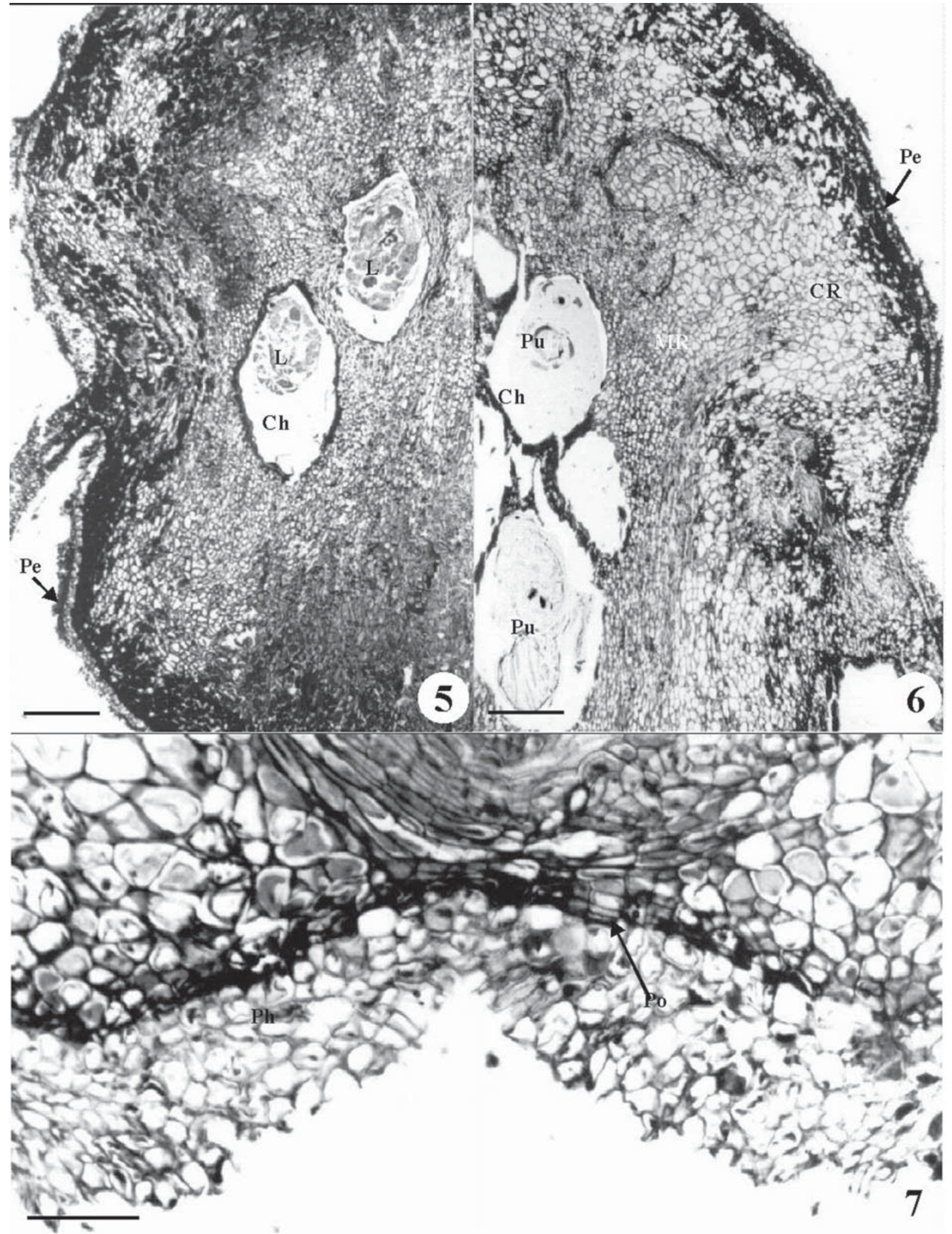

Figures 5-7. Struthanthus vulgaris leaf galls, transverse sections. 5. Stage 4 gall (part of the structure). Note the periderm and the gall-makers (late larval phase). Bar $=1 \mathrm{~mm}$. 6. Stage 5 gall (part of the structure). Note the periderm and hypertrophied cortical cells. The gall-makers are in pupal phase. Bar $=1 \mathrm{~mm}$. 7. Detail of the periderm: the phellem is conspicuous. The phellogen is indicated by arrow. $\mathrm{Bar}=100 \mu \mathrm{m} . \mathrm{Ch}=$ Chamber, $\mathrm{CR}=$ Cortical Region, $\mathrm{L}=$ Larva, $\mathrm{MR}=$ Medullar Region, $\mathrm{Pe}$ $=$ Periderm, $\mathrm{Ph}=$ Phellem, $\mathrm{Po}=$ Phellogen, $\mathrm{Pu}=$ Pupa. 


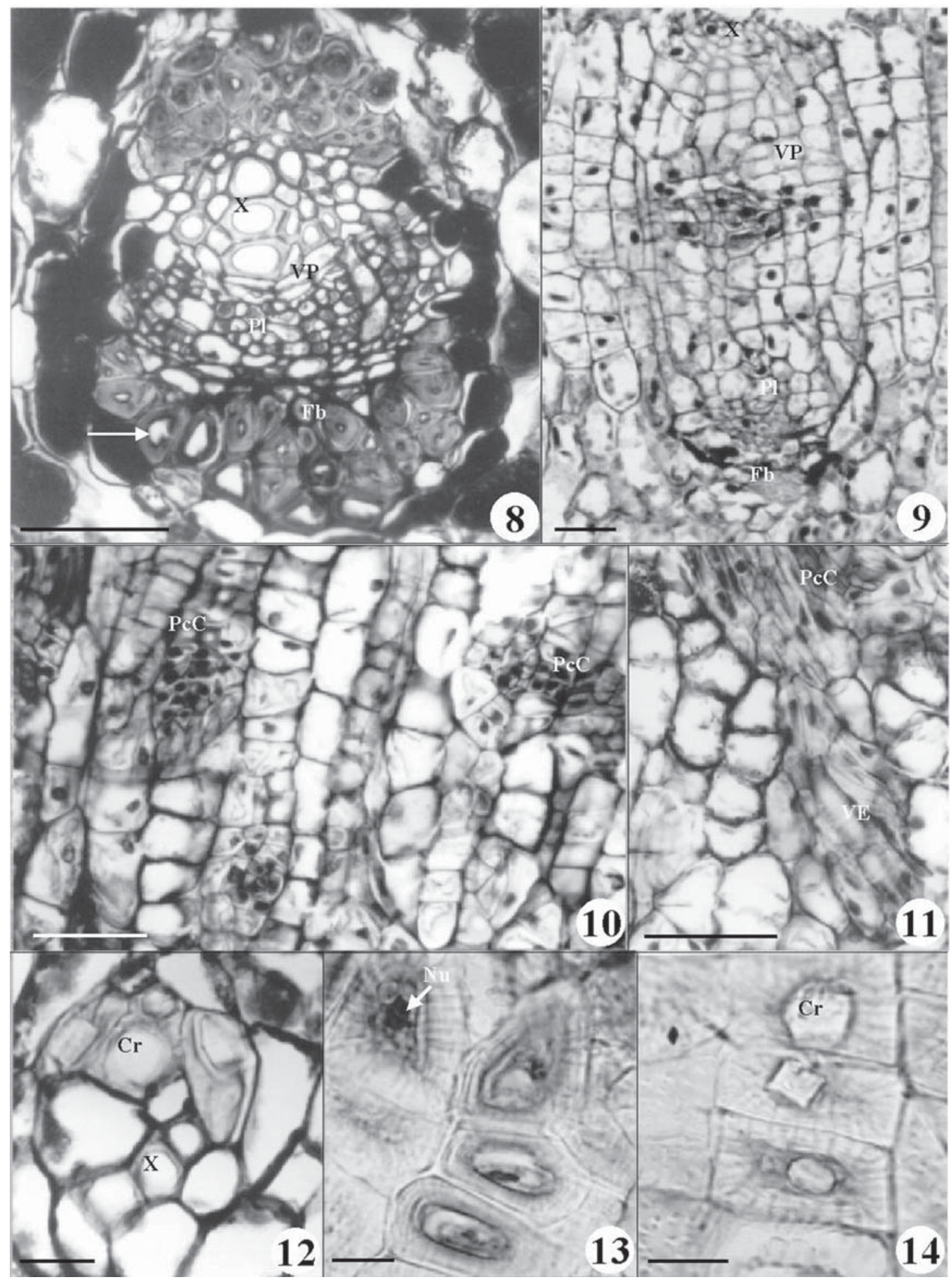

Figures 8-14. Struthanthus vulgaris leaf galls, transverse sections. 8. Vascular bundle of the early stage 2 gall. Some pericyclic fibers have reduced secondary walls (arrow). Bar $=50 \mu \mathrm{m}$. 9. Affected vascular bundle of the late stage 2 gall. Note the hyperplasia of the vascular parenchyma, which separates the xylem from the phloem. The pericyclic fibers are losing their lignified walls. Bar $=10 \mu \mathrm{m} .10-11$. Stage 3 gall. 10. Detail of the procambial cells in the neoformed tissue. Bar $=25 \mu \mathrm{m} .11$. Detail of the differentiation of the procambial cells into vascular elements. Bar $=25 \mu \mathrm{m}$. 12. Sclereids with crystals losing their lignified wall in early stage 2 gall. Bar $=10 \mu \mathrm{m}$. 13-14. Stage 3 gall. 13. Detail of the new-formed sclereids. Note their nucleus. $\mathrm{Bar}=10 \mu \mathrm{m} .14$. Mature new-formed sclereids, with their crystals. Bar $=10 \mu \mathrm{m} . \mathrm{Cr}=\mathrm{Crystal}, \mathrm{Fb}=$ Fiber, $\mathrm{Nu}=\mathrm{Nucleus}, \mathrm{PcC}$ $=$ Procambial Cell, $\mathrm{Pl}=$ Phloem, $\mathrm{VE}=$ Vascular Element, $\mathrm{VP}=$ Vascular Parenchyma, $\mathrm{X}=$ Xylem. 
The gall in the fifth developmental stage (figure 6) reaches its definitive size. The cortical cells undergo slight hypertrophy and they become larger and more vacuolated than the medullar ones. The gall-makers are in pupal phase (figure 17). The inducer chamber is lined with two or three layers of densely cytoplasmatic cells that form a hard structure.

The adult gall-makers open galleries (exit channel), cutting the gall tissues with their mouthparts and leaving the waste in the chamber (figure 18). The senescent stage is characterized by the presence of small orifices on the gall surface. After the emergence of the gall-makers, the cells close to the chamber (figure 19) and the exit channel (figure 20) divide, forming two or three layers, similar to a protective layer. The gall tissues remain alive for some weeks after inducer's emergence. Later the gall tissues disintegrate, but the periderm remains almost intact until leaf abscission.

\section{Discussion}

It is not yet clear how the insect galls are induced, but the insect secretions as amino acids, phenolic compounds and phenol oxidases, pectinases and proteases (Hori 1992) may be involved in cecidogenesis. Recent research indicates that hormones (Leitch 1994, De Bruyn et al. 1998, Mapes \& Davies 2001a,b) are also involved in the gall morphogenesis. However, it is known that interaction with insects belonging to two different taxa results in the formation of morphologically distinct galls (Meyer \& Maresquelle 1983, Meyer 1987, Krishnan \& Franceschi 1988, Arduin et al. 1989, 1991).

It is interesting to note that the galls under study, induced by Hymenoptera, exhibit the same structural modifications during the initial developmental stage as do galls observed by Arduin et al. (1991), induced by Diptera (Cecidomyiidae). During gall development, the mesophyll is competent for anaplasia and the chlorenchyma cell characteristics are lost as a consequence of the development of neoformed parenchyma cells on both galls.

In the gall studied, the neoformed parenchyma is resulted from hypertrophy and hyperplasia of the spongy parenchyma cells in the initial phase, but later the palisade parenchyma also undergoes hyperplasia. Therefore the spongy parenchyma cells responds more rapidly to the insect stimulus than the palisade parenchyma, perhaps because the preferred site of insect attack is at the abaxial surface (Arduin et al. 1989), so the cecidogenic field is nearer to the spongy parenchyma. However, the spongy parenchyma cells of leaf fragments cultured in vitro also respond first (Geier 1976 apud Fink 1999), indicating the greater competence of this tissue.

The vascular system of the hymenopteran gall described here also exhibits the same alterations as seen in the dipteran gall (Arduin et al. 1991), the most important change being the hyperplasia of the vascular parenchyma.

Another relevant observation is the modification of pericyclic fibers and sclereids during the $S$. vulgaris gall formation. The pericyclic fibers and sclereids are living cells that lose their secondary walls. This process seems to be controlled and unique to fibers and sclereids. Secondary walls of xylem elements, which are enclosed by pericyclic fibers, do not disintegrate. Similar effects were observed in the leaf gall induced by the cecidomyiid (Arduin et al. 1991), but they seem not to be peculiar to $S$. vulgaris galls, as they occur in other plant galls (Arduin \& Kraus 1995, 2001, Souza et al. 2000). The pericycle is a tissue that retains its meristematic capacity, so the dedifferentiation of their cells simultaneously with the process of delignification is easily comprehended. However, for sclereids, few examples of delignification are provided in the literature, and this process is associated with the ripening of the fruits, indicating that the enzymatic activity is of the protoplast of the sclereid itself (Alexandrov \& Djaparidze 1927). The sclereids of $S$. vulgaris leaf galls are another example of living cells which undergo delignification.

The presence of phenolic substances mostly in the superficial portion of the neoformed parenchyma, in the hymenopteran $S$. vulgaris leaf gall, point to chemical defense in this gall. This feature was also observed in the dipteran gall (Arduin et al. 1991). According to Cornell (1983), the presence of phenolics indicates a chemical defense mechanism, because they are thought inhibit the feeding of herbivorous insects, or the parasite community of the insect gall (Taper \& Case 1987).

As a leaf gall of $S$. vulgaris induced by Hymenoptera matures, it develops its own morphology, differing in size, shape and structural aspects from the Diptera galls. According to Bronner (1992) and Rohfritsch (1992), the gall morphogenesis seems to be associated with the inducer's nutritional physiology. Larval feeding activity, mainly models the shape of the larval chamber, and the development of gall tissues, ceases concomitantly with the maturity of the insect. Our results are in agreement with the observations of these authors; the gall structure is modified during gall 
development and no further modifications when the inducers are in pupal phase and no more nutritive tissue is present.

Another relevant characteristic is the presence of a periderm in the hymenopteran gall. The presence of periderm on healthy leaves is rare, and it is suggested that leaf periderm is a consequence of insect or mechanical injuries, or develops beneath microorganisms (Fahn 1990). However, some galls develop periderm (Meyer \& Maresquelle 1983, Krishnan \& Franceschi 1988). The gall caused by a species of Cynipidae (Hymenoptera) on the leaf of Rosa woodsii has a periderm, and the gall induced by Eurytoma sp. (Hymenoptera) is hairy (Krishnan \& Franceschi 1988). The presence of periderm on galls is discussed by Meyer \& Maresquelle (1983)

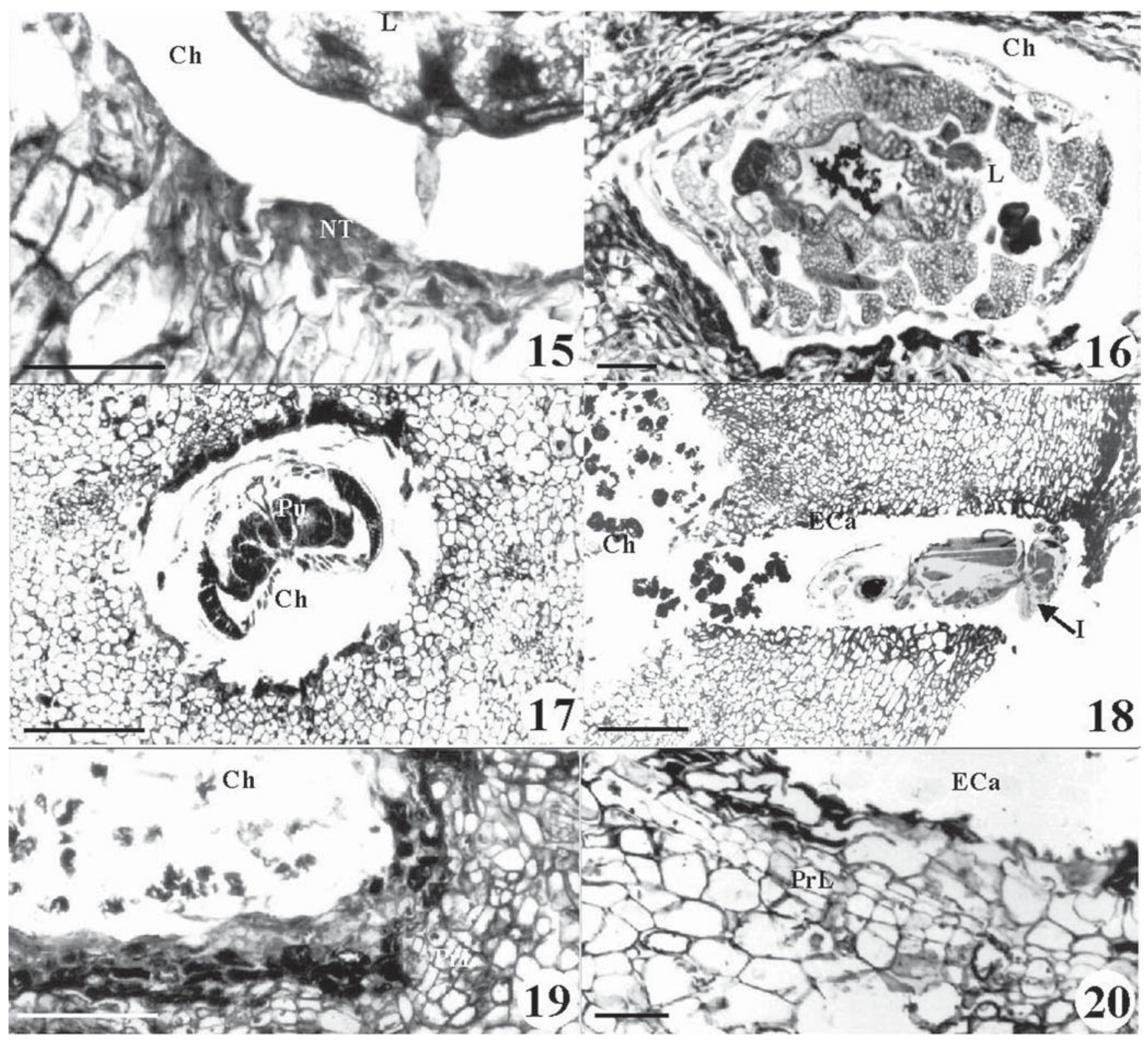

Figures 15-20. Struthanthus vulgaris leaf galls, transverse sections. 15. Stage 3 gall. Note the nutritive tissue. Bar $=2,5 \mu \mathrm{m}$. 16. Stage 4 gall. The nutritive tissue is no longer observed. The inducer is in late larval phase. Bar $=100 \mu \mathrm{m}$. 17. Stage 5 gall. Note the inducer in the pupal phase. $\mathrm{Bar}=100 \mu \mathrm{m} .18-20$. Senescent gall. 18. Note the exit channel with the imago. Bar= $100 \mu \mathrm{m} .19$. Detail of the chamber, showing the protective layers. Bar $=100 \mu \mathrm{m}$. figure 20. Detail of the exit channel, showing the protective layers. Bar $=100 \mu \mathrm{m} . \mathrm{Ch}=$ Chamber, $\mathrm{ECa}=$ Emergence Channel, $\mathrm{I}=$ Imago, $\mathrm{L}=\mathrm{Larva}, \mathrm{NT}=$ Nutritive Tissue, $\operatorname{PrL}=$ Protective Layer, $\mathrm{Pu}=$ Pupa. 
as a form of mechanical protection. The suberized tissues, like the lignified ones, are considered anti-herbivorous structures (Feeny 1970, 1975, 1976, Harborne 1990).

At gall senescence, around the insect chamber and the exit channel a tissue that resembles the protective layer of the abscission zone of the leaves is observed. The formation of this protective layer shows that the gall tissues exhibit responses even after the inducer has left.

Rohfritsch (1992) has proposed that the cynipid gall model causes profound modifications in the plant tissues. Although the gall-makers of $S$. vulgaris belong to another Hymenoptera family, their galls showed profound modifications too. The galls studied also provoked different and more conspicuous modifications in the leaf tissues than the galls caused by Cecidomyiidae (Diptera) (Arduin et al. 1991) in the same host plant. As observed by Krishnan \& Franceschi (1988), the interactions of insects belonging to different families results in the formation of leaf galls that are morpho-histologically distinct. Such modifications are largely determined by the insects, which cause these neoformed outgrowths, in order to provide shelter and food for the inducer.

The present study has also shown that the galls of $S$. vulgaris are not an uncontrolled tumor growth. Their ontogeny follows a well-defined sequence, and produces an equally well-defined morpho-anatomical structure. These alterations reveal the plasticity of plant tissues, which may be controlled by insects. Our findings confirm the conclusions of Taft \& Bissing (1988) that not only the presence of the inducer leads to a rupture of the cellular process of the host, but it also results in an active redirection of the existing ontogenetic patterns, to the benefit of the inducer(s). Indeed Schönrogge et al. (2000) detected proteins similar to protein seeds in gall tissues, suggesting that gall formation might involve the ectopic expression of genes of other structures of the host plant.

Comparing the development of the $S$. vulgaris leaf gall induced by Hymenoptera with that induced by Diptera (Arduin et al. 1991) it is suggested that these different insects can affect similar key processes, at least initially, but during the maturation of each gall specific key processes are elicited, leading to different cecidogenesis.

Acknowledgements - The authors are grateful to the CNPq (Grants 301776/83 and 823028/87).

\section{References}

ALEXANDROV, W.G. \& DJAPARIDZE, L.I. 1927. Über das Entholzen und Verholzen der Zellhaut. Planta 4:476-475.

ARDUIN, M. \& KRAUS, J.E. 1995. Anatomia e ontogenia de galhas foliares de Piptadenia gonoacantha (Fabales, Mimosaceae). Boletim de Botânica, Universidade de São Paulo 14:109-130.

ARDUIN, M. \& KRAUS, J.E. 2001. Anatomia de galhas de ambrosia em folhas de Baccharis concinna e Baccharis dracunculifolia (Asteraceae). Revista Brasileira de Botânica 24:63-72.

ARDUIN, M., KRAUS, J.E., OTTO, P.A. \& VENTURELLI, M. 1989. Caracterização morfológica e biométrica de galhas foliares em Struthanthus vulgaris Mart. (Loranthaceae). Revista Brasileira de Biologia 49:817-823.

ARDUIN, M., KRAUS, J.E. \& VENTURELLI, M. 1991. Estudo morfológico de galha achatada em folha de Struthanthus vulgaris Mart. (Loranthaceae). Revista Brasileira de Botânica 14:147-156.

BHATNAGHAR, S.P. \& JOHRI, B.M. 1983. Embryology of Loranthaceae. In The biology of the mistletoes (D.M. Calder \& P. Bernhardt, eds.). Academic Press, Sidney, p.47-66.

BRONNER, R. 1992. The role of nutritive cells in the nutrition of cynipids and cecidomyiids. In Biology of insect-induced galls (J.D. Shorthouse \& O. Rohfritsh, eds.). Oxford University Press, New York, p.117-192.

CALDER, D.M. 1983. Mistletoes in focus: an introduction. In The biology of the mistletoes (D.M. Calder \& P. Bernhardt, eds.). Academic Press, Sidney, p.1-17.

CORNELL, H.V. 1983. The secondary chemistry and complex morphology of galls formed by the Cynipinae (Hymenoptera): why and how? American Midland Naturalist 110:225-234.

DE BRUYN, L., VANDEVYVERE, I., JAMINÉ, D. \& PRINSEN, E. 1998. The effects of gall formation by Lipara lucens (Diptera, Chloropidae) on its host Phragmites australis (Poaceae). In The biology of gallinducing arthropod (G. Csóka, W.J. Mattson, G.N. Stone \& P.W. Price, eds.). USDA, Forest Service, St. Paul, p.173-187.

FAHN, A. 1990. Plant anatomy. Pergamon Press, Oxford.

FEENY, P. 1970. Seasonal changes in oak leaf tannins and nutrients as a cause of spring feeding by winter moth caterpillars. Ecology 51:565-581.

FEENY, P. 1975. Biochemical coevolution between plants and their herbivores. In Coevolution of animals and plants (L.E. Gilbert \& P.H. Raven, eds.). University of Texas Press, Austin, p.3-19.

FEENY, P. 1976. Plant appearance and chemical defense. Recent Advances in Phytochemistry 10:1-40. 
FERNANDES, G.W., ARAÚJO, R.C., ARAÚJO, S.C., LOMBARDI, J.A., PAULA, A.S., LOYOLA JR, R. \& CORNELISSEN, T.G. 1997. Insect galls from savanna and rocky fields of Jequitinhonha Valley, Minas Gerais, Brazil. Naturalia 22:221-224.

FERNANDES, G.W., TAMEIRÃO-NETTO, E. \& MARTINS, R.P. 1988. Ocorrência e caracterização de galhas entomógenas na vegetação do campus Pampulha da Universidade Federal de Minas Gerais. Revista Brasileira de Zoologia 5:11-19.

FINK, S. 1999. Pathological and regenerative plant anatomy. Gebrüder Borntraeger, Berlin.

HARBORNE, J.B. 1990. Constraints on the evolution of biochemical pathways. Biological Journal of the Linnean Society 39:135-151.

HAWKSWORTH, F.G. 1983. Mistletoes as forest parasites. In The Biology of the mistletoes (D.M. Calder \& P. Bernhardt, eds.). Academic Press, Sidney, p.317-327.

HORI, K. 1992. Insect secretions and their effect on plant growth, with special reference to hemipterans. In Biology of insect-induced galls (J.D. Shorthouse \& O. Rohfritsh, eds.). Oxford University Press, New York. p.157-170.

JOHANSEN, D.A. 1940. Plant microtechnique. McGraw-Hill Book Co., New York.

KRAUS, J.E., SOUSA, H.C., REZENDE, M.H., CASTRO, N.M., VECCHI, C. \& LUQUE, R. 1998. Astra blue and basic fuchsin double staining for plant material. Biotechnic \& Histochemistry 73:235-243.

KRISHNAN, H.B. \& FRANCESCHI, V.R. 1988. Anatomy of some leaf galls of Rosa woodsii (Rosaceae). American Journal of Botany 75:369-376.

KUIJT, J. 1969. The biology of parasitic flowering plant. University California Press, Berkeley.

LARA, A.C. \& FERNANDES, G.W. 1996. The highest diversity of the galling insects: Serra do Cipó, Brazil. Biodiversity Letters 3:111-114.

LEITCH, I.J. 1994. Induction and development of the bean gall caused by Pontania proxima. In Plant galls: organisms, interactions, populations (M.A.J. Williams, ed.). Clarendon Press, Oxford, p.283-312.

LIMA, E.S., MAGENTA, M.A.G., KRAUS, J.E., VECCHI, C. \& MARTINS, S.E. 2000. Levantamento preliminar de galhas entomógenas em plantas das restingas de Bertioga, SP. In $\mathrm{V}$ Simpósio de Ecossistemas Brasileiros: conservação (S. Watanabe, coord.). Aciesp, São Paulo, v.3, p.39-46.

MAIA, V.C. 1999. Cecidomyiinae (Diptera), Cecidomyiidae das Restingas da Barra de Maricá, Itaipuaçu e Carapebus (Rio de Janeiro, Brasil): descrição e dados biológicos. Tese de doutorado, Universidade Federal do Rio de Janeiro, Rio de Janeiro.

MAPES, C.C. \& DAVIES, P.J. 2001a. Indole-3-acetic acid and ball gall development on Solidago altissima. New Phytologyst 151:195-202.
MAPES C.C. \& DAVIES, P.J. 2001b. Cytokinins in the ball gall of Solidago altissima and in the gall forming larvae of Eurosta solidaginis. New Phytologyst 151:203-212.

MARVIER, M.A. \& SMITH, D.L. 1997. Conservation implications of host use for rare parasitic plants. Conservation Biology 11:839-848.

MEYER, J. 1987. Plant galls and galls inducers. Gebrüder Borntraeger, Berlin.

MEYER, J. \& MARESQUELLE, H.J. 1983. Anatomie des galles. Gebrüder Borntraeger, Berlin.

MONTEIRO, R.F., FERRAZ, F.F.F., MAIA, V.C. \& AZEVEDO, M.A.P. 1994. Galhas entomógenas em restingas. Uma abordagem preliminar. In III Simpósio de Ecossistemas da Costa Brasileira: subsídios a um gerenciamento ambiental (S. Watanabe, coord.). Aciesp, São Paulo, v.3, p.210-220.

NORTON, D.A. \& CARPENTER, M.A. 1998. Mistletoes as parasites: host specificity and speciation. Trends in Ecology \& Evolution 13:101-105.

PRICE, P.W., FERNANDES, G.W., LARA, A.C., BRAWN, J., BARRIOS, H., WRIGHT, M.G., RIBEIRO, S.P \& ROTHCLIFF, N. 1998. Global patterns in local number of insect galling species. Journal of Biogeography 25:581-591.

ROHFRITSH, O. 1992. Patterns in gall development. In Biology of insect-induced galls (J.D. Shorthouse \& O. Rohfritsh, eds.). Oxford University Press, New York. p.60-86.

RÜBSAAMEN, E.H. 1915. Beitrag zur Kenntnis aussereuropäischer Gallmücken. Sitzugsberichte der Gesellschaft Naturforschender Freunde, Berlin 1:432-433.

SALATINO, A., KRAUS, J.E. \& SALATINO, M.L. 1993. Contents of tannins and their histological localization in young and adults parts of Struthanthus vulgaris Mart. (Loranthaceae). Annals of Botany 72:409-414.

SASS, S.E. 1951. Botanical microtechnique. The Iowa State College, Iowa.

SCHÖNROGGE, K., HARPER, L.J. \& LICHTENSTEIN, C.P. 2000. The protein content of tissues in cynipid galls (Hymenoptera: Cynipidae): similarities between cynipid galls and seeds. Plant, Cell and Environment 23:215-222.

SOUZA, S.C., KRAUS, J.E. ISAIAS, R.M.S. \& NEVES, L.J. 2000. Anatomical and ultrastructural aspects in Ficus microcarpa L. f. (Moraceae) induced by Gynaikothrips ficorum Marchal (Thysanoptera). Acta Botanica Brasilica 14:57-69.

TAFT, J.B. \& BISSING, D.R. 1988. Developmental anatomy of the horned oak gall induced by Callirhythis cornigera on Quercus palustris (pin oak). American Journal of Botany 75:26-36. 
TAPER, M.L. \& CASE, T.J. 1987. Interactions between oak tannins and parasite community structure: unexpected benefits of tannins to cynipid gall-wasps. Oecologia 71:254-261.

TAVARES, J.S. 1921. Cecidologia brazileira. Cecídias que se criam em plantas das famílias Leguminosae, Sapotaceae, Lauraceae, Myrtaceae, Punicaceae, Umbelliferae, Loranthaceae, Apocynaceae, Urticaceae, Salicaceae e Gramineae. Brotéria, série Zoológica 19:76-112.
VENTURELLI, M. 1984. Estudos sobre Struthanthus vulgaris Mart.: aspectos anatômicos de raiz adventícia, caule e folha. Revista Brasileira de Botânica 7:79-89.

VENTURELLI, M. \& KRAUS, J.E. 1989. Morphological and anatomical aspects of the primary haustorium of Struthanthus vulgaris Mart. (Loranthaceae) in vitro. Revista Brasileira de Botânica 12:17-22.

WEBER, H.C. 1987. Preface. In Parasitic plants (H.C. Weber $\&$ W. Forstreuter, eds.). Proceedings of the $4^{\text {th }}$ International Symposium on Parasitic Flowering Plants, Phillips Universität, Marburg. p.VII-VIII. 